\title{
The Evolution of Crowdfunding Towards an Impact Investing Logic: The Case of Paulownia Social Project
}

\author{
Rosangela Feola, Roberto Parente \\ University of Studies of Salerno, Fisciano, Italy \\ Tommaso D’Onofrio \\ Confindustria Innovation and Technology Services, Roma, Italy \\ Ezio Marinato, Dario Pellegrino \\ University of Studies of Salerno, Fisciano, Italy
}

\begin{abstract}
In the last years, crowdfunding is arising as a widespread financing and fundraising tool, allowing to turn a large audience of customers into investors, individuals who can supply financial capital. Thus, crowdfunding represents a novel mechanism of fundraising embedded in the current financial innovation, which operates in order to produce convergent innovations that produce both economic and social outcomes. Studies are mainly aimed to understand which factors led a crowdfunding campaign towards the success. The whole research aims to analyse the new emerging financial tool, known as crowdfunding, with the purpose to understand and explain how it collaborates with the main traditional financial mechanisms used by enterprises. This study leds the author to recognize a new emerging shape for the crowdfunding, a structure which allows to take advantage of the traditional limits of funds of investment. Thus, both the capability to attract a great number of investors and the social content of the project-to-fund represent the push to move the crowd investment towards impact investing. The newness of the topic, the lack of certain and various data, the youth of the analyzed phenomenon, and the explorative nature of the research, pushed the authors to choose a case study approach.
\end{abstract}

Keywords: crowdfunding, social innovation, financial innovation, impact investing

\section{Introduction}

The crowdsourcing revolution (Howe, 2006) started a process of rethinking the access to knowledge-based resources, assimilating the key concepts and basis of co-creation process (Normann \& Ramirez, 1993) through the disintermediation of web-based platforms, digital technologies, and online communities that even enhance the access to financial resources (Agrawal, Catalini, \& Goldfarb, 2011; Laubacher, 2012; Bryniolfsson \&

Rosangela Feola, Ph.D., Research Fellow, Department of Business Sciences - Management and Innovation Systems, University of Studies of Salerno. Email: emarinato@unisa.it.

Roberto Parente, Full Professor, Department of Business Sciences - Management and Innovation Systems, University of Studies of Salerno.

Tommaso D’Onofrio, Vice-President, AISCRIS - Association of Italian Consulting Firms for Research, Innovation and Development, Confindustria Innovation and Technology Services.

Ezio Marinato, Ph.D., Researcher, Department of Business Sciences - Management and Innovation Systems, University of Studies of Salerno.

Dario Pellegrino, Ph.D., Researcher, Department of Business Sciences - Management and Innovation Systems, University of Studies of Salerno. 
McAfee, 2014). In the context of stakeholder approach (Freeman, 1984), integrated in a quintuple helix model (Carayannis \& Campbell, 2009), these activities directly affect all the ecosystems where enterprises live, translating themselves into an evolutionary step of innovation towards social innovation that solves some of nowadays criticalities (Christensen, Baumann, Ruggles, \& Sadtler, 2006; Schenk \& Guittard, 2011; Guida \& Maiolini, 2013), especially the financial one through the crowdfunding (Landström, 1992; 1993; Schwienbacher \& Larralde, 2010; Ordanini, Miceli, Pizzetti, \& Parasuraman, 2011; Freund, 2012; Gerber, Hui, \& Kuo, 2012; Miglietta, Parisi, Pessione, \& Servato, 2013; Wheat, Wang, Byrnes, \& Ranganathan, 2013; Belleflamme, Lambert, \& Schwienbacher, 2014; Marlett, 2015). Recently, crowdfunding opened to an easy access to the widespread financial resources unlocking the firms to fundraise their developmental activities in their early stage. Thus, crowdfunding seems to show its capability to produce a social impact (Slootweg, Vanclay, \& van Schooten, 2001; Shaw \& Carter, 2007; Bull, 2007; Nicholls, 2009; Arvidson, Lyon, McKay, \& Moro, 2010; Lane \& Casile, 2011; Barraket \& Yousefpour, 2013; Estévez, Walshe, \& Burgman, 2013) especially considering its vocation to fund social enterprises, which underline the new crowd investing shape very close to the impact investing phenomenon.

From the analysis of the current literature, what emerges is the lack of the attention about the role of both the social impact of crowdfunding and the influence of project-to-fund social content on the result of a crowdfunding campaign. Starting from these premises, in this explorative study, the authors focalize their attention on the relation between crowdfunding and impact investing. They aim to identify which are the financial mechanisms to serve the social enterprises via the observation of an equity crowdfunding campaign launched to fundraise an entrepreneurial project with a social vocation.

In particular, the authors studied the equity crowdfunding investment, relying on the behaviour of many European countries, which are tending to regulate and support equity crowdfunding in order to supply equity to small and medium enterprises (SMEs). The purpose is to understand how the social orientation of a start-up project, in the meaning of the creation of social outcomes, could influence the success of a crowdfunding campaign led on an equity-based platform. Specifically, adopting a case study approach, the authors observed the evolution and the results of a crowdfunding campaign that involved both an equity crowdfunding platform "Assiteca Crowd" and a social project by a start-up called "Paulownia", which was able to collect more than $€ 500 \mathrm{k}$ (27\% from professional investors) from 12 investors.

The research shows that crowdfunding could be helpful to both raise financial-based resources for innovative companies and produce social outcomes to the benefit of all the interested communities. Our research could have implication for both entrepreneurs (especially innovative companies) and crowdfunding platform owner, in order to set up an effective and succeeding crowdfunding industry.

\section{Literature Review}

\section{Social Impact}

The interest among scholars about social impact is growing faster, because of nowadays changes in the entrepreneurial and business framework. Taking the necessary differences, the study about the new emerging social entrepreneurship movements and theoretical antecedents by Shaw and Carter (2007) underlined how the new shape of social enterprises is tending to the for-profit characterization. This view agrees with Porter and Kramer (2011) idea about a reinvention of capitalism towards a structure characterized by businesses shaped around the creating shared value concept, to unlock the next wave of business innovation and growth. 
Tout court, there is no more need of a trade-off between profits and social needs. That means a new way to intend and measure the impact of for-profit activities on the society.

The International Committee on Guidelines and Principles for Social Impact Assessment (ICGP), in the year 2003, defined social impact as "the consequence to human populations of any public or private actions that alter the ways in which people live, work, play, relate one to another, organize to meet their needs and generally cope as members of society. The term also includes cultural impact involving changes to the norms, values and beliefs that guide and rationalize the cognition of themselves and their society”. According to Slootweg et al. (2001) and Estévez et al. (2013), social impact could be deconstructed into two main concepts: social changes and human impacts. The two concepts are strongly related through a causal relationship, which affects the decision-making processes and the capture and measurement of social impact itself, because of social criteria that may be both positive and negative, depending on the changing perceptions (Burdge \& Vanclay, 1995; Vanclay, 2002).

Social impact concerns the outcomes that hit a specified community in terms of social performances that could be translated in the wide spread social value, which means the result of the social enterprises activities on their stakeholders. In contradiction with financial values, the social ones are qualitative and less rigorous, implying that social impact may be not easy to measure (Bull, 2007; Nicholls, 2009; Arvidson et al., 2010; Lane \& Casile, 2011; Barraket \& Yousefpour, 2013). However, Bagnoli and Megali (2011) argued that there is a strong relationship between inputs and organizational processes of an enterprise and the outputs and outcomes that identify the social impacts.

\section{Impact Investing}

The attention about social impact is even the key factor of the current financial industry tendency, which is focused on the fostering of impact investing or other financial investing mechanisms that could produce both financial and social returns (Harji \& Jackson, 2012; Louche, Arenas, \& van Cranenburgh, 2012; Höchstädter \& Scheck, 2015; Nicholls, 2010).

Impact investing is a rather new phenomenon whose definition is strongly related to the capability to create a social impact as well as a financial return on investment (Clarkin \& Cangioni, 2016) by matching philanthropic aims, government action, and profit-seeking investment (Freireich \& Fulton, 2009). There is a trait d'union between social impact and impact investing, because the second aims to reach goals in both economical and social fields, using financial models of investment with a social responsible peculiarity and focusing on creating positive social or environmental impact.

The current literature (Freireich \& Fulton, 2009; Nicholls, 2010; Harji \& Jackson, 2012; Louche et al., 2012; Martin, 2013; Clarkin \& Cangioni, 2016; Höchstädter \& Scheck, 2015) is positioning under the definition of impact investing different manifestations known as social finance, social impact investing, or blended value investing, and all the financing instruments created to gain both social and financial returns (Bagwell, 2012). Short, Moss, and Lumpkin (2009) identified the opportunities reserved by impact investing in the research to expand the role of financing and in the research to find a new way to finance social ventures. In fact, following the evolution from social responsibility to social innovation, the growth of social entrepreneurship, in the meaning of an organized effort to address solution to social issues, is going through a maturation phase that opens new frontiers for the financing community (Clarkin \& Cangioni, 2016). This is strongly linked to "the change in capitalism”, described by Porter and Kramer (2011) in their "creating sharing value” study, which shows a new way to approach a profit-oriented firm that should be socially and environmentally driven. 
Thus, this new emerging industry has started to create network and metrics to measure its value through the measurement of the social impact, which is usually seen as a qualitative variable (Jackson, 2013; Clarkin \& Cangioni, 2016). The need for a measure of impact investing through the social impact measurement has been shortly satisfied by the Impact Reporting and Investment Standards (IRIS), which offers a common set of definitions, and the Global Impact Investing Rating System (GIIRS), an analogue of the Standard and Poor's or Morningstar rating systems, uses a common set of indicators to measure the social performance (Jackson, 2013).

The possibility to give a measure of the impact, the new generation of business and socially savvy entrepreneurs that is launching ventures across an array of regions and sectors, and the cash-strapped government (Bugg-Levine \& Emerson, 2011) are the reasons behind the creation of a great number of impact investment funds (Höchstädter \& Scheck, 2015).

\section{Crowdfunding}

Crowdfunding has recently drawn the attention of both scholars and professionals as an outstanding financial tool. Because of its evolutionary nature, from its birth this financial mechanism has experienced a lot of changes, with a common driver: the capability to adapt the crowdfunding model to many different fields.

From the analysis of the current literature, what emerges is the lack of the attention about the role of both the social impact of crowdfunding and the influence of project-to-fund social content on the result of a crowdfunding campaign.

For this reason, in this explorative study, the authors focalize their attention on the relation between crowdfunding and impact investing. In particular, the authors studied the equity crowdfunding investment, relying on the behaviour of many European countries which are tending to regulate and to support equity crowdfunding, in order to supply equity to small and medium enterprises (SMEs). In fact, after the Italian experience about equity crowdfunding regulation (Decree Law "Crescita 2.0", converted in law in 2012), other European countries are, similarly, designing specific regulation.

On one hand, Landström (1992; 1993) argued that the equity gap challenge represents the highest barrier to overcome for every start-up company. The difficulties, in fact, increase when the financial sub-pillar, in a specific regional system, is not effective. This leads to the need of researching alternative financial tools that could be considered as a complement or a substitute of traditional and formal investment mechanisms (Wright, Lockett, Clarysse, \& Binks, 2006).

On the other hand, crowdsourcing revolution (Howe, 2006) and technology platforms started a disintermediation process that changed the dynamics of integration economies (Piller, Moeslein, \& Stotko, 2004) between the broad types of user and producer. Crowdsourcing is influencing innovation processes, through a mechanism of interaction between the providers and the seekers of strategic resources. At the beginning, the strategic resources involved in this interaction were mainly knowledge-based resources, but nowadays the financial-based resources are becoming a relevant aspect of crowdsourcing, thanks to crowdfunding.

In the last years, crowdfunding is arising as a widespread financing and fundraising tool, which allows turning a large audience of customers into investors (Schwienbacher \& Larralde, 2010; Ordanini et al., 2011; Belleflamme et al., 2014). These authors agree with the idea that crowdfunding lies on different elements that could be macro-categorized in: web, social (relational) capital (Bordieu, 1985), financial resources and, indeed, crowdsourcing (Poetz \& Schreier, 2012). The need to feed a strong wide community highlights the social network structure of crowdfunding, but as Mollick (2014) argued, this investment vehicle takes the steps from the evolution of micro-finance (Morduch, 1999). 
Crowdfunding is a funding vehicle that embraces different contexts as well as social, civic, and academic ones (Giannola \& Riotta, 2013; Davies, 2014a). It literally connects entrepreneurs with potential funders, or rather individuals who can supply financial capital (Wheat et al., 2013; Marlett, 2015).

According to prior studies, crowdfunding intervenes as a motivational crowdwork factor (Gerber et al., 2012; Miglietta et al., 2013) that permits to pass over the barriers linked to proximity and credit crunch (Freund, 2012). This is possible thanks to the intermediation internet-based platforms, which act as a market place where it is possible to collect and canalize the scattered unlocked private capitals to sustain business ideas from research, decreasing the weight of geographical proximity in the innovation process (Agrawal et al., 2011).

Crowdfunding could be classified into two macro-areas: token crowdfunding and investing crowdfunding (Schwienbacher \& Larralde, 2010). Token crowdfunding encompasses the different expressions of donation crowdfunding, which is a donation-based model, i.e., charity online fundraising campaign. Instead, investing crowdfunding can be further broken down into passive investment and active investment. The passive investment encloses the lending-based and reward-based models, which differ one another from the type of return provided for the investors. The active investment, essentially, defines the equity-based model, which is going to be the most important crowdfunding manifestation for the SMEs. Looking at a generalized context, crowdfunding, on the whole, acts in different but correlated directions: supplies financial resource, offers markets insights, and lets the SMEs to engage in venture capital (Wardrop, Zhang, Rau, \& Gray, 2015). Thus, crowdfunding represents an alternative finance market. Following the presented peculiarities of investing crowdfunding, it could be considered as a subset of crowdfunding in the whole that could be easily defined as crowdinvesting. Crowdinvesting allows people to directly answer to the financial resource need expressed by a specified project. This financing mechanism was born in 2012 and its industry produced \$28 billion in $2015\left(1^{\circ}\right.$ Report Italiano sul Crowdinvesting, 2016). The most diffused expression of crowdinvesting is the equity crowdfunding model which allows individuals to subscribe, via web-based platforms, equity shares of a company which runs a crowdfunding campaign. USA and Italy were the first countries which have tried to introduce the alternative financing mechanism. Italy was the first to release in 2012 a crowdfunding regulation included in the Law Decree "Sviluppo-Bis" and ruled by the CONSOB (National Securities and Exchange Commission) even though the most representative market is the United Kingdom where CrowdCube, the main crowdfunding platform, raised £168 million. The above quoted regulation allows Italian start-ups, small business and financial vehicles which invest in them to access to the equity crowdfunding as long as they interact through a CONSOB authorized platform.

To date, Italian crowdfunding platforms, since its first appearance with the foundation of Produzioni Dal Basso $^{1}$ in 2005, have shown a compound annual growth rate (CAGR) of 85.7\% from 2005 to 2015 that is expected to turn into $63.9 \%$ at the end of 2016, considering the upcoming new crowdfunding platforms. Looking at the insights from the market in 2014, the success rate of the crowdfunding campaign launched on the different living platforms (Osservatorio Crowdfunding, 2016) is about 30\% in the mean. The success rate of crowdfunding campaigns launched on an equity platform is $33 \%$. The total volume of investments made via crowdfunding platforms in 2015 is $€ 56.8$ million, with a growth rate of 85\% from 2014. More than €1.6 millions come from the registered 13 equity crowdfunding platforms. Moreover, $34 \%$ of the launched campaign clearly expressed their social vocation as well as their mission to address solutions to social issues.

\footnotetext{
${ }^{1}$ Produzioni Dal Basso is a reward and donation crowdfunding platform, born in 2005, which works in the DIY digital productions. In 2013, it had been established and registered as an innovative start-up.
} 
Focusing on equity crowdfunding, the " $1{ }^{\circ}$ Report italiano sul Crowdinvesting" (2016) showed that the mean volume of investment specified in the target of each crowdfunding campaign is $€ 317 \mathrm{k}$ with an offer for equity of $23 \%$, which corresponds with a prodigal pre-money evaluation of $€ 1$ million. Although the total amount of the financial resources raised is $€ 5.6$ million that is under the expectation and the potentiality of the market. These are some of the criticalities of this model that, together with the almost absolute absence of the rights of vote linked to the subscribed shares, express the light and shades of the equity crowdfunding mechanism.

So, studies are mainly aimed to understand which factors led a crowdfunding campaign towards the success, taking the steps from the work on fundraising in venture capital context (MacMillan, Zemann, \& Subbanarasimha, 1987; Baum \& Silverman, 2004; Dushnitsky \& Shaver, 2009; Dushnitsky, 2010). Some authors (Mollick, 2014; Agrawal et al., 2011) noticed a relevant impact of quality signals, social network ties, appropriate goals, and careful planning on the success of a campaign. Moreover, the experience of civic crowdfunding in few European countries (Gray, 2013; The Economist, 2013; Hollow, 2013; Davies, 2014b) showed how the probability to produce widespread social benefits catalyses people in order to fund projects and to reach the expected funding goal. Thus, the social element seems to be crucial as well the above quoted ones.

Looking at the equity crowdfunding model, this influence expressed by the social vocation seems to be unclear, unless scholars will steer the attention to social enterprises.

Going in depth of the source of financial need, considering the composition of a community made by individuals with different needs, the entrepreneurial and financial institutions have to face a huge variety of formulation of intents, so they are influenced by a lot of actors, according to the stakeholder theory. All these individuals could be grouped into many niches that crowdfunding phenomenon seems to be able to engage, following the evidence of the application of the long tail theory (Anderson, 2006).

Thus, crowdfunding represents a novel mechanism of fundraising embedded in the current financial innovation (Moenninghoff \& Wieandt, 2013), which operates in order to produce convergent innovation (Dubé, Jha, Faber, Struben, London, Mohapatra, ..., \& McDermott, 2014). It means innovation that produces both economic and social (human) outcomes. These aspects clarify the increasing attention from scholars and practitioners on this financial tool. Even governments are interested in crowdfunding, the U.S. Government, for example, was the first who put its attention on this new investment vehicle, understanding the inner potential represented by crowdfunding for the new emerging enterprises. Government like the Italian one decided to study the phenomenon and released regulations about crowdfunding. USA, India, and Turkey are moving in the same way (Bruton, Khavul, Siegel, \& Wright, 2015).

\section{Purpose/Thesis}

The aim is to understand how the social direction of a start-up project, in the meaning of the creation of social outcomes, could influence the success of a crowdfunding campaign led on an equity-based platform. Specifically, the authors observed the evolution and the results of a crowdfunding campaign that involved both an equity crowdfunding platform “Assiteca Crowd” and a social project by a start-up called "Paulownia”, which was able to collect more than $€ 500 \mathrm{k}$ ( $27 \%$ from professional investors) from 12 investors.

Following the evidence of the literature review, the authors have noticed a gap about the study of the impact of social vocation on the success of a crowdfunding campaign. This paper aims to identify which are the financial mechanisms to serve the social enterprises via the observation of an equity crowdfunding campaign launched to fundraise an entrepreneurial project with a social vocation. A case study approach is adopted to draw the shape of 
equity crowdfunding applied to a social enterprise. Throughout a study about the experience of the start-up "Paulownia" and the crowdfunding host platform "Assiteca Crowd", the authors focalized their attention on the importance of the shared value creation and social vocation in leading a successful crowdfunding campaign.

The authors try to answer the question about the failure of modern finance and capitalism in harnessing social issues. According to the literature review, it means that equity crowdfunding is moving towards the impact investing.

\section{Methodology}

The newness of the topic, as well as the lack of certain and various data, the peculiar youth of the analyzed phenomenon and, moreover, the explorative nature of the research, pushed the authors to choose a case study approach (Yin, 2009).

To be clear, the authors' aim is to identify and understand a specific phenomenon, relatively new in literature. Therefore, the research is designed as a qualitative and epistemological investigation with a holistic approach. The authors built a single case study research, borrowing elements and characterization from the grounded theory (Strauss \& Corbin, 1990; 1998; Charmaz, 2008).

Eisenhardt (1989) explained that one or more cases are useful to develop theories about some specific topics. Because of the current framework, it could be useful to follow an inductive development of the theory that aspires to recognize and describe the existence of a phenomenon (Siggelkow, 2002; 2007). Through conceptual exercise and question (Siggelkow, 2002; 2007), the authors start a case-based research, with empirical evidence collected by observation of participants (Burgess, 2002), studying a single case.

In the way to strengthen this assumption, looking at a single case, it takes the start for the attempt to research a meaning and to give a sense to the observed phenomenon, from a local and contextual perspective (Burgess, 2002).

At the beginning, the authors look at crowdfunding in the whole, and then they focus on the equity crowdfunding model as the greatest expression of active crowd-investment model, which is the core of this work, considering that many European countries are tending to regulate equity crowdfunding, in order to supply equity to SMEs. In fact, after the Italian experience about equity crowdfunding regulation (Decree Law "Crescita 2.0", converted in law in 2012), other European countries are, similarly, designing specific regulation. Then, the authors went in depth the topic collecting the needed data from different sources, database and by the adoption of different methods. Therefore, data were collected first from the web and then from the insight of the Assiteca Crowd platform. Then, the authors continued to gather data from the observation and by interviewing the Paulownia spokesperson.

Results were analysed in comparison with the context interpretation.

\section{Case}

In order to define what may concern the relationship between crowdfunding and impact investing, this study investigates a case study about an equity crowdfunding campaign led on an Italian equity crowdfunding platform "Assiteca Crowd".

The authors investigated Paulownia Social Project srl, an innovative start-up with a social vocation, created by a team of experts coming from the renewable energy sector, agriculture and environmental protection. Its mission is to develop plantations of fast-growing trees, activities also known as Short Rotation Forestry (SFR), in order to allocate the raw material obtained, in both national and international timber sectors. Its crowdfunding 
campaign was hosted on the Assiteca Crowd equity-based platform, an Italian web-based portal where the equity fundraising is legal, regulated, and safe. Assiteca Crowd is one of the Italian crowdfunding platforms certified by the CONSOB.

The reasons why the authors decided to investigate Paulownia crowdfunding campaign lean on the awareness that this innovative start-up experienced the most successful fundraising activities via web-based platform. Table 1 shows the best crowdfunding projects, among which Paulownia Social Project srl is the second best within all the successful campaigns, but the first within the equity crowdfunding successful campaigns. Assiteca Crowd hosted for 56 days the Paulownia campaigns that are the days it needed to gather about €520k from 12 investors.

Table 1

The Six Most Successful Campaigns Led on an Italian Crowdfunding Platform (2015-2016)

\begin{tabular}{|c|c|c|}
\hline Projects & Platform & $€$ \\
\hline Ricostruiamo Città della Scienza & DeRev & $1,463,867.00$ \\
\hline Paulownia Social Project & Assiteca Crowd & $520,000.00$ \\
\hline BIOerg & Next Equity & $452,576.00$ \\
\hline Cantiere Savona & Starsup & $380,000.00$ \\
\hline Un passo per San Luca & Ginger & $339,743.00$ \\
\hline E' l'ora della solidarietà: emergenza Sardegna & Rete del Dono & $138,896.00$ \\
\hline
\end{tabular}

This experience seems to represent one of the best practices that support the idea about crowdfunding as a financial instrument, able to support SMEs to face the equity gap challenge in their start-up stage. In fact, the case of Paulownia represents an edge case, which is useful to indicate how equity crowdfunding applied to a "slightly" social enterprise could fulfill the aspirations about creating both profits and positive social and environmental impact. Data were collected, for the first instance, from the platform to recognize the main characteristics of the campaign itself and the aspects related to the investors, their investments, and their geographic localization.

Mainly, the company's purpose is the development, production, and marketing of innovative products or services with high technological value applied to the forestry in Italy. Paulownia developed patented new plant varieties and acquired under license others, in order to use selected samples to ensure rapid growth, excellent quality of the timber, and maximum absorption of carbon dioxide from the atmosphere. The social activities will be carried out taking care of the optimization of production processes and the identifiability of the product, also through innovative tools, so that the timber produced by the company can be marketed on the community market in order to support the community supply of wood or biomass ensuring traceability, as required by the EU and national legislation in force. From the environmental point of view, the production of Paulownia, made by the company, will contribute significantly to the reduction of carbon dioxide emitted into the atmosphere and, therefore, the company can carry out any activity to enhance the environmental benefits generated by the project. In addition, the company may perform ancillary activities on forestry and compatible with them, such as the production of organic honey in the same object main activity sites, vocational training and social education addressed to junior high and high school students, realizing special school educational programs and participation in university research projects. The company is considered an innovative start-up with a social vocation. The company may carry out all the business, financial, investment and real estate that the administrative organ deems useful or necessary for the implementation of activities that constitute the corporate purpose. 
The activities that Paulownia Social Project intends to carry out concretely relate to forestry in Sicily, in the Trapani province, of fast-growing trees, an activity also known as SFR. The trees belong to the Paulownia species, considering its capacity for growth, the fastest in the world, its qualitative skills, and the very high absorption capacity of carbon dioxide. In particular, it has been selected the clone In Vitro 112® (Patent: EU No. 010881704 registered on September 25, 2012). The selected clone was genetically engineered in the laboratory in 1972, which has been proven to have superior characteristics, for adaptability to different types of soil and different weather conditions, compared with other types of Paulownia. The company intends to proceed every four years to cutting and wood product sales for a 20-year cycle, and then the contribution of biomass to roots.

Looking at its crowdfunding campaign, Paulownia Social Project srl stood up the standard behavior of equity crowdfunding campaign: in fact, while a common Italian crowdinvesting campaign offers $23 \%$ of the shares, Paulownia Social Project offered $87 \%$ of its equity, reflected on its equity value. The pre-money evaluation of Paulownia Social Project, in the light of the previous considerations about its campaign, is far under the market mean value of $€ 2$ million and is equal to $€ 80,000.00$, really cautious.

Paulownia Social Project, thanks to equity crowdfunding Assiteca Crowd platform, reached the target of 520,000 Euros and welcomed 12 new members in its equity. In less than two months (56 days), with an extraordinary average daily collection of more than €9,000.00, the Paulownia project reached new fundraising record.

Looking at the investors, nine of them are private individuals and three are companies; considering the Italian crowdfunding regulation constraints, to follow the rules, the last mile of the crowdfunding campaign was run by the financial vehicle of Assiteca Crowd. In 56 days, Paulownia registered, via Assiteca Crowd, a minimum investment per investors of $€ 15,000$ and a maximum investment of 140,000 (the mean volume of investment is about $€ 43,333$ ). This performance, compared with a prior study of Vecchi, Casalini, and Caselli (2016) investigating the development of a company both from a traditional financial approach and an impact investing approach, suggests how crowdfunding campaign applied to a social vocated enterprise falls in the middle of a seed stage and early stage financing. According to Vecchi et al. (2016), in the pre-seed and seed stages, financing family and friends and business angels intervene in a high-tech start-up financing as well as donors and venture philanthropy intervene in social impact enterprise financing; equally, in the early stage, financing venture capital intervenes in the high-tech start-up financing as well as impact investing intervenes in social impact enterprise financing.

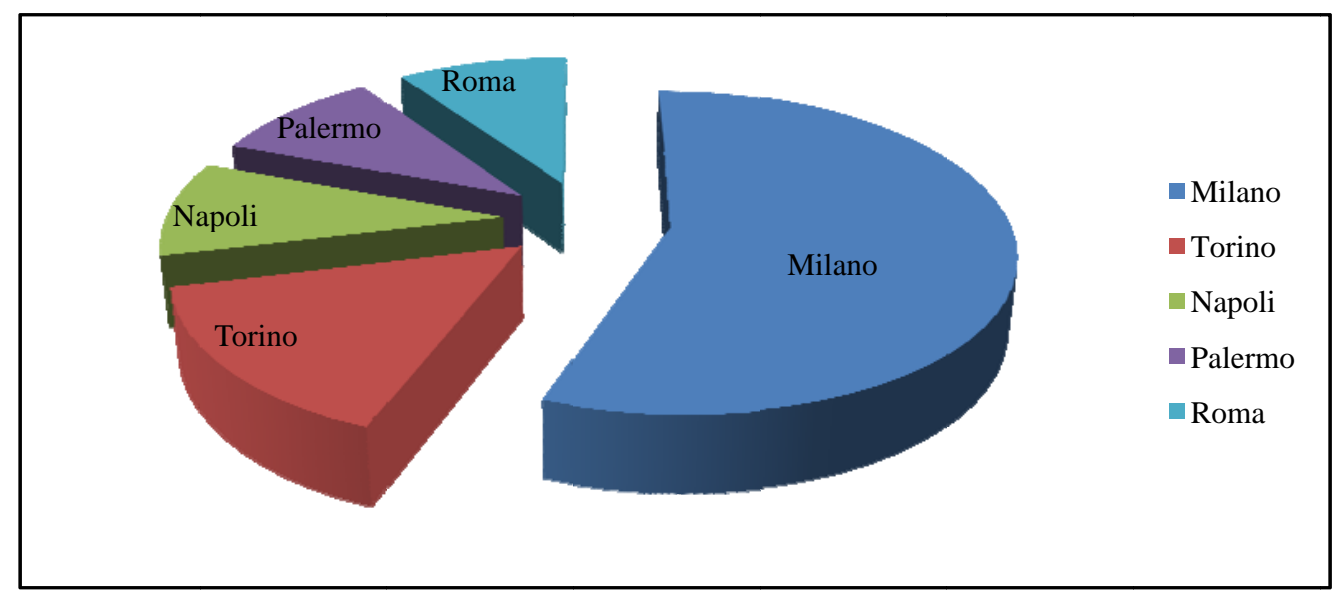

Figure 1. Geographical dispersion of Paulownia Social Project investors. Source: Self-elaboration, 2016. 
The analysis of the campaign launched Paulownia Social Project shows, in Figure 1, how the distance between creators and investors is non-influential. The authors noticed the heterogeneity of the geographical background of the backers. The 12 investors who backed the entrepreneurial project came from different regions across the Italian country. This information agrees with Agrawal et al.'s (2011) observations about weight of distance perceived by individuals who interact through internet-based platforms applied to the crowdfunding, meaning that geography dispersion within investors and between the start-up and investors is not relevant.

\section{Findings}

This approach is expected to capture the complexity of the phenomenon.

This study leads the authors to recognize a new emerging shape for the equity crowdfunding. In fact, if the need to reinvent the capitalism structure, leveraging on the shared value creation, identified the configuration of impact investing, the democracy of the web and, in particular, of the equity crowdfunding platforms, open the financial world to a new structure which allows taking advantage of the traditional limits of funds of investment. Thus, both the capability to attract a great number of investors, according to Anderson's (2006) long tail model, and the social content of the project-to-fund, represent the push to move the crowd investment towards impact investing.

Moreover, the experience of Paulownia highlights the tie between equity crowdfunding (or rather crowd investment) and the traditional finance, which could be represented as a puzzle of pieces derived from the corporate finance. In fact, following the evidence from the study of Miglietta, Pessione, and Servato (2012), the case of Paulownia shows some similarities with the venture philanthropy. Miglietta et al. (2012) discussed about the main characteristics that identify venture philanthropy:

(1) High relationship: venture philanthropists have intense relationships with stakeholders;

(2) Project financing: venture philanthropists, as well as venture capitalists, design and plan their investment according to both the target and the alternatives (debt, equity, mezzanine capital, loans, etc.);

(3) Long-time support: a three to five years investing strategy;

(4) Non-financial support: a plus that goes over the simple financial support, in order to provide services for planning, strategy, marketing, etc.;

(5) Organizing skills strengthening: financing operating costs to help companies to reach their goal and survive along a long period horizon;

(6) Performance measurement.

It goes without saying that these venture philanthropy characteristics are close to the main peculiarities of venture capital, business angels, and venture incubators.

Considering the investment volume for each investor and their kind of legal personality, the results (see Table 2) underline similarities with the Italian venture capital market in 2015 (see Figure 2) and the first Italian crowdfunding report (Osservatorio Crowdfunding, 2016) which shows how crowdfunding is able to collect only a "small crowd" of investors strongly represented by holding companies, real estate companies, business angels, and high net worth individuals. 
Table 2

Legal Personality, Origin, Investment Amount, and Business Sector for Each Paulownia Investor

\begin{tabular}{|c|c|c|c|c|}
\hline Project & Paulownia Social Project & & & \\
\hline Kind & Origin & Amount & Share & Sector \\
\hline $\mathrm{JP}$ & Milano & 140,000 & $23.33 \%$ & Holding company \\
\hline JP & Torino & 30,000 & $5.00 \%$ & Real estate \\
\hline PP & Buccinasco (MI) & 15,000 & $2.50 \%$ & n.d. \\
\hline JP & Torino & 50,000 & $8.33 \%$ & Property management \\
\hline PP & Napoli & 15,000 & $2.50 \%$ & n.d. \\
\hline PP & Trezzano sul Naviglio & 35,000 & $5.83 \%$ & n.d. \\
\hline PP & Piana degli Albanesi (PA) & 50,000 & $8.33 \%$ & n.d. \\
\hline PP & Roma & 50,000 & $8.33 \%$ & n.d. \\
\hline PP & Buccinasco (MI) & 20,000 & $3.33 \%$ & n.d. \\
\hline PP & Milano & 30,000 & $5 \%$ & n.d. \\
\hline PP & Milano & 50,000 & $8.33 \%$ & n.d. \\
\hline \multirow[t]{4}{*}{ PP } & Napoli & 35,000 & $5.83 \%$ & n.d. \\
\hline & & 520,000 & $86.67 \%$ & \\
\hline & & 80,000 & $13.33 \%$ & Shareholders/projectors \\
\hline & & & $100.00 \%$ & \\
\hline
\end{tabular}

Notes. PP = Physical person; JP = Juridical person. Source: Assiteca Crowd, 2016.

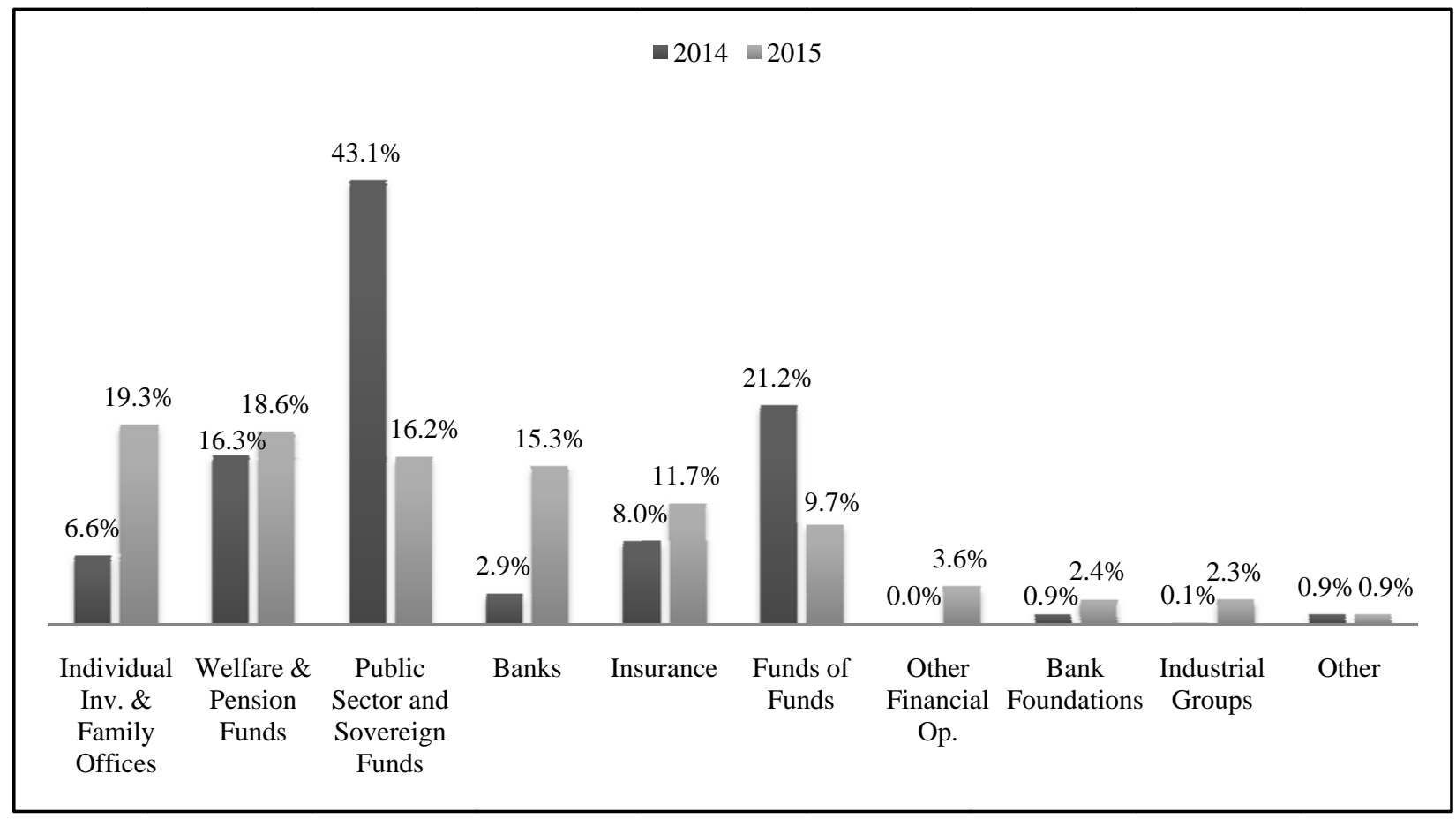

Figure 2. Italian venture capital market in 2014-2015. Source: AIFI (2015).

The coexistence of different legal personalities, with the common intention to invest in a social impact enterprise to collect financial returns, shows likeness with italian impact investing funds as described by Vecchi, Casalini, Cusumano, and Brusoni (2014) via the Oltre Venture experience, at the time of writing one of the first impact investment funds in Europe, which gathered an investment commitment from equity investors, who accepted the social impact challenge mainly with a philanthropic mindset. 
The success of Paulownia crowdfunding campaign agrees with a prior study of some of the authors (Parente, Feola, \& Marinato, 2015) in which they compared the results of 16 successful and unsuccessful campaigns, noticing that successful campaigns have at least one patent, even if it cannot be considered a success predictor (see Table 3), but mainly, it could be considered as a catalyst of financial resources (see Figure 3).

Table 3

A Comparison Between Campaigns

\begin{tabular}{ll}
\hline & Average no. of patent \\
\hline Successful & 1.2 \\
Unsuccessful & 3.8 \\
\hline
\end{tabular}

Note. Source: Self-elaboration, 2016.

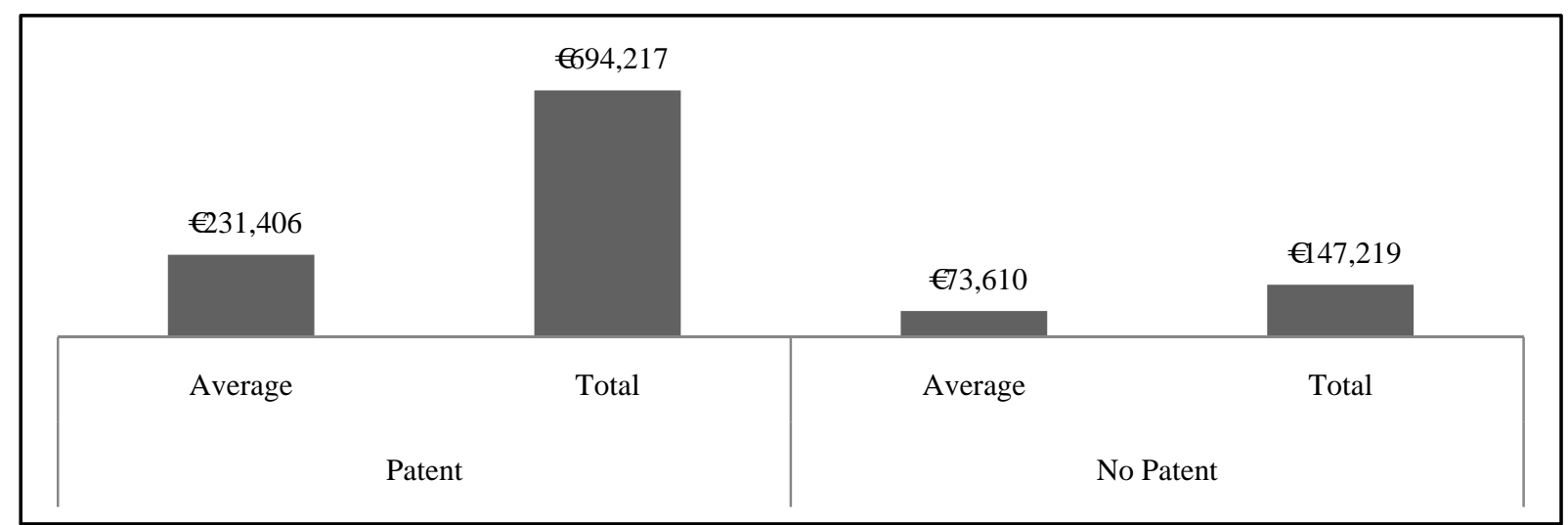

Figure 3. Total and average volume of financial resources attracted by successful campaigns, classified by patent registration or not. Source: Self-elaboration, 2016.

Moreover, according to the case studied, a successful campaign has shown a shorter campaign duration and the capability to attract financial resources faster (see Figure 4). In fact, Paulownia was able, as above quoted, to collect the whole financial resources in 56 days.

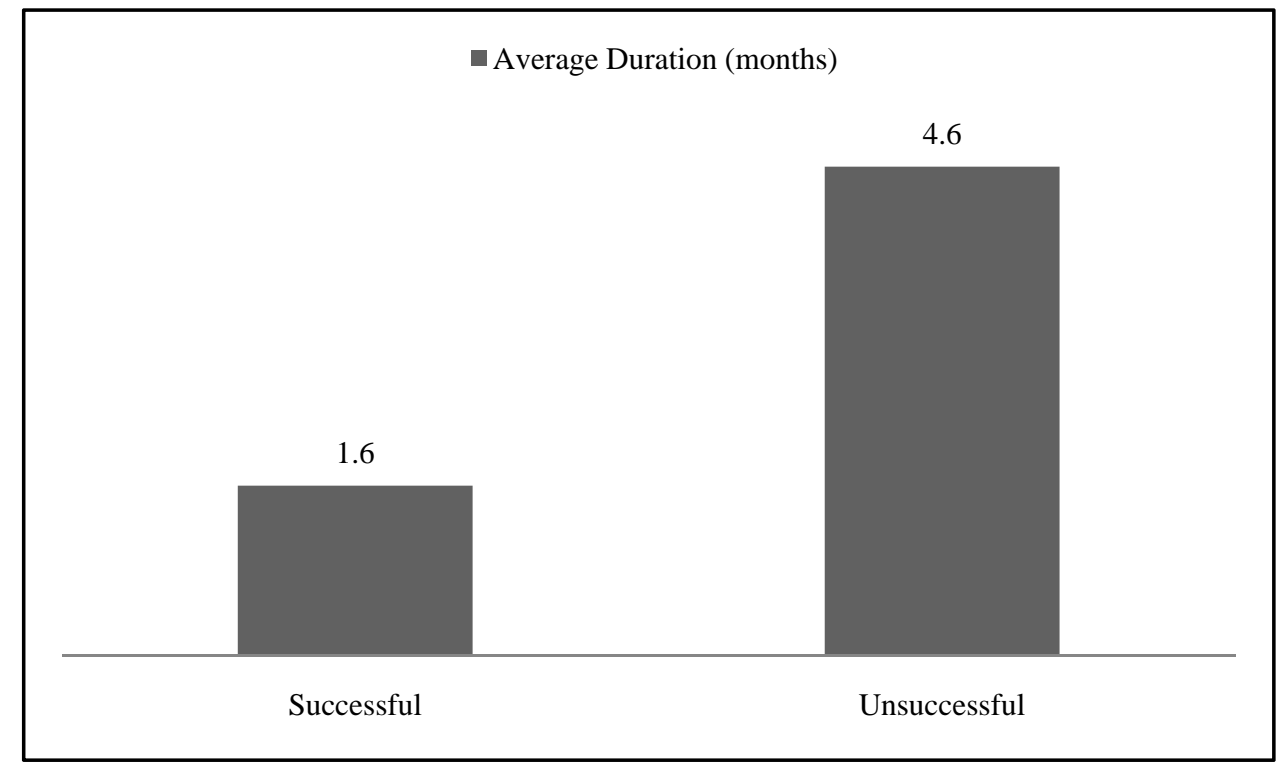

Figure 4. Crowdfunding campaign average duration, in months. Source: Self-elaboration, 2015. 
On the financial side, it is interesting to see how Paulownia s.r.l. adopted option contacts typical of traditional equity financing, as a shareholders concession: in the end of the 5th, the 10th and the 15th exercise, following that on which the capital increase has been realized, and for the consecutive 30 days, retail investors have the right to sell their own shares to the founders at the subscription price, plus a 7\%, up to a cumulative maximum of $30 \%$ of the subscribed equity. Within 30 days' exercise on put option, the founders could exercise the right to buy all the investors' shares that exerted on put option at the same price.

\section{Conclusion}

Thus, considering the fundraising performances of Paulownia, equity crowdfunding platforms act like an equity market place that links the seed stage financing to early stage financing and it implies that the authors' intuition about a change in the shape of crowdinvesting is correct. In fact, the investors operations suggest a translation of equity crowdfunding, also known as crowdinvesting, towards impact investing.

Summarizing, the authors understood that crowdfunding could be helpful to both raise financial-based resources for innovative companies and produce social outcomes to the benefit of all the interested communities. Moreover, this research could help both entrepreneurs (especially innovative companies) and crowdfunding platform owner, to set up an effective and succeeding crowdfunding industry.

\section{Further Research}

The authors initially intend to enlarge the sample, including all innovative start-ups. This would be useful to conduct a quantitative research, in order to understand better the role of crowdfunding, the importance of a social attitude as a quality sign and the evolution of this fundraising mechanism towards the impact investing. Then, the authors suggest mapping the crowdfunding phenomenon across the Europe, in the way to start a case study within different countries to understand how cultural aspects and regulations affect the evolution of crowdfunding in a specific country.

\section{References}

Agrawal, A. K., Catalini, C., \& Goldfarb, A. (2011). The geography of crowdfunding. NBER Working Paper No. 16820.

AIFI. (2015). Il mercato italiano del PE e VC nel 2014.

Anderson, C. (2006). The long tail: Why the future of business is selling less of more. New York, NY: Hyperion.

Arvidson, M., Lyon, F., McKay, S., \& Moro, D. (2010). The ambitions and challenges of SROI. TSRC Working Paper 49.

Bagnoli, L., \& Megali, C. (2011). Measuring performance in social enterprises. Nonprofit and Voluntary Sector Quarterly, 40(1), 149-165.

Bagwell, S. (2012). “Social investment: An introduction”. In NPC Briefing. London: New Philanthropy Capital. Retrieved from http://www.thinknpc.org/publications/social-investment/

Barraket, J., \& Yousefpour, N. (2013). Evaluation and social impact measurement amongst small to medium social enterprises: Process, purpose and value. Australian Journal of Public Administration, 72(4), 447-458.

Baum, J. A., \& Silverman, B. S. (2004). Picking winners or building them? Alliance, intellectual, and human capital as selection criteria in venture financing and performance of biotechnology startups. Journal of Business Venturing, 19(3), 411-436.

Belleflamme, P., Lambert, T., \& Schwienbacher, A. (2014). Crowdfunding: Tapping the right crowd. Journal of Business Venturing, 29(5), 585-609.

Bordieu, P. (1985). The forms of capital. In J. G. Richardson (Ed.), Handbook of theory and research for the sociology of education (pp. 241-258). New York, NY: Greenwood Press.

Bruton, G., Khavul, S., Siegel, D., \& Wright, M. (2015). New financial alternatives in seeding entrepreneurship: Microfinance, crowdfunding, and peer-to-peer innovations. Entrepreneurship Theory and Practice, 39(1), 9-26. 
Bryniolfsson, E., \& McAfee, A. (2014). The second machine age: Work, progress, and prosperity in a time of brilliant technologies. W. W. Norton \& Company.

Bugg-Levine, A., \& Emerson, J. (2011). Impact investing: Transforming how we make money while making a difference. Innovations, 6(3), 9-18.

Bull, M. (2007). "Balance”: The development of a social enterprise business performance analysis tool. Social Enterprise Journal, 3(1), 49-66.

Burdge, R. J., \& Vanclay, F. (1995). Social impact assessment. In F. Vanclay, \& D. A. Bronstein (Eds.), Environmental and social impact assessment (pp. 31-65).

Burgess, R. G. (2002). In the field: An introduction to field research. Routledge.

Carayannis, E. G., \& Campbell, D. F. (2009). 'Mode 3' and 'quadruple helix': Toward a 21st century fractal innovation ecosystem. International Journal of Technology Management, 46(3-4), 201-234.

Charmaz, K. (2008). Constructionism and the grounded theory method. In Handbook of constructionist research (pp. 397-412). New York, NY: Guilford Press.

Christensen, C. M., Baumann, H., Ruggles, R., \& Sadtler, T. M. (2006). Disruptive innovation for social change. Harvard Business Review, 84(12), 94-101.

Clarkin, J. E., \& Cangioni, C. (2016). Impact investing: A primer and review of the literature. Entrepreneurship Research Journal, $6(2), 135-173$.

Davies, R. (2014a). Civic crowdfunding: Participatory communities, entrepreneurs and the political economy of place.

Davies, R. (2014b). Civic crowdfunding as a marketplace for participation in community development. Paper presented at the IPP2014.

Dubé, L., Jha, S., Faber, A., Struben, J., London, T., Mohapatra, A., ..., \& McDermott, J. (2014). Convergent innovation for sustainable economic growth and affordable universal health care: Innovating the way we innovate. Annals of the New York Academy of Sciences, 1331(1), 119-141.

Dushnitsky, G. (2010). Entrepreneurial optimism in the market for technological inventions. Organization Science, 21(1), $150-167$.

Dushnitsky, G., \& Shaver, J. M. (2009). Limitations to interorganizational knowledge acquisition: The paradox of corporate venture capital. Strategic Management Journal, 30(10), 1045-1064.

Eisenhardt, K. M. (1989). Building theories from case study research. Academy of Management Review, 14(4), 532-550.

Estévez, R. A., Walshe, T., \& Burgman, M. A. (2013). Capturing social impacts for decision-making: A multicriteria decision analysis perspective. Diversity and Distributions, 19(5-6), 608-616.

Freeman, R. E. (1984). Stakeholder management. A strategic approach. New York, NY: Pitman.

Freireich, J., \& Fulton, K. (2009). Investing for social \& environmental impact: A design for catalyzing an emerging industry. Cambridge, MA: Monitor Institute.

Freund, R. (2012). How to overcome the barriers between economy and sociology with open innovation, open evaluation and crowdfunding? International Journal of Industrial Engineering and Management, Martin-Luther University, 1(3), 107-109.

Gerber, E. M., Hui, J. S., \& Kuo, P. Y. (2012). Crowdfunding: Why people are motivated to participate. Paper presented at the ACM Conference on Computer Supported Cooperative Work.

Giannola, E., \& Riotta, E. F. P. (2013). Crowdfunding civico: Finanziamento collet-tivo come strategia di innovazione sociale. Urbanistica DOSSIER, 603.

Gray, K. (2013). Built by the crowd: The changing world of public infrastructure. Wired UK, 4 November. Retrieved from http://www.wired.co.uk/magazine/archive/2013/11/features/built-by-the-crowd

Guida, M. F., \& Maiolini, R. (2013). Il fattore C per l'innovazione sociale. Rubbettino, SoveriaMannelli (CZ).

Harji, K., \& Jackson, E. T. (2012). Accelerating impact: Achievements, challenges and what's next in building the impact investing industry. New York, NY: The Rockefeller Foundation.

Höchstädter, A. K., \& Scheck, B. (2015). What's in a name: An analysis of impact investing understandings by academics and practitioners. Journal of Business Ethics, 132(2), 449-475.

Hollow, M. (2013). Crowdfunding and civic society in Europe: A profitable partnership? Open Citizenship, 4(1), 68-73.

Howe, J. (2006). The rise of crowdsourcing. Wired Magazine, 14(6), 1-4.

Jackson, E. T. (2013). Evaluating social impact bonds: Questions, challenges, innovations, and possibilities in measuring outcomes in impact investing. Community Development, 44(5), 608-616.

Landström, H. (1992). The relationship between private investors and small firms: An agency theory approach. Entrepreneurship \& Regional Development, 4(3), 199-223. 
Landström, H. (1993). Informal risk capital in Sweden and some international comparisons. Journal of Business Venturing, 8(6), 525-540.

Lane, M. D., \& Casile, M. (2011). Angels on the head of a pin: The SAC framework for performance measurement in social entrepreneurship ventures. Social Enterprise Journal, 7(3), 238-258.

Laubacher, R. (2012). Entrepreneurship and venture capital in the age of collective intelligence. MIT Center for Collective Intelligence Working Paper No. 2012-02.

Louche, C., Arenas, D., \& van Cranenburgh, K. (2012). From preaching to investing: Attitudes of religious organisations towards responsible investment. Journal of Business Ethics, 110(3), 301-320.

MacMillan, I. C., Zemann, L., \& Subbanarasimha, P. N. (1987). Criteria distinguishing successful from unsuccessful ventures in the venture screening process. Journal of Business Venturing, 2(2), 123-137.

Marlett, D. (2015). Crowdfunding art, science and technology. A quick survey of the burgeoning new landscape. Leonardo, 48(1), 104-105.

Martin, M. (2013). Making impact investible. Impact Economy Working Papers, Vol. 4.

Miglietta, A., Parisi, E., Pessione, M., \& Servato, F. (2013). Crowdfunding and local governments: A financial opportunity for a new liaison with citizens. Paper presented at the 16th Toulon-Verona Conference “Excellence in Services” (pp. 485-495), University of Ljubljana, Slovenia.

Miglietta, A., Pessione, M., \& Servato, F. (2012). Il territorio e lo sviluppo dell'imprenditorialità sociale: il caso Ivrea 24. Attidel XXIV Convegnoannuale di Sinergie.

Moenninghoff, S. C., \& Wieandt, A. (2013). The future of peer-to-peer finance. Schmalenbachs Zeitschrift für betriebswirtschaftliche Forschung, 65(5), 466-487.

Mollick, E. (2014). The dynamics of crowdfunding: An exploratory study. Journal of Business Venturing, 29(1), 1-16.

Morduch, J. (1999). The microfinance promise. Journal of Economic Literature, 37(4), 1569-1614.

Nicholls, A. (2009). We do good things, don't we? Blended value accounting in social entrepreneurship. Accounting, Organizations and Society, 34(6-7), 755-769.

Nicholls, A. (2010). The legitimacy of social entrepreneurship: Reflexive isomorphism in a pre-paradigmatic field. Entrepreneurship Theory and Practice, 34(4), 611-633.

Normann, R., \& Ramirez, R. (1993). From value chain to value constellation: Designing interactive strategy. Harvard Business Review, 71(4), 65-77.

Ordanini, A., Miceli, L., Pizzetti, M., \& Parasuraman, A. (2011). Crowd-funding: Transforming customers into investors through innovative service platforms. Journal of Service Management, 22(4), 443-470.

Osservatorio Crowdfunding. (2016). $1^{\circ}$ Report Italiano sul Crowdinvesting. Retrieved from http://www.economyup.it/upload/images/06_2016/160628164939.pdf

Parente, R., Feola, R., \& Marinato, E. (2015). Financing the academic spin-off companies: The role of crowdfunding. Technology Transfer Society Annual Conference, Dublin, 2015.

Piller, F. T., Moeslein, K., \& Stotko, C. M. (2004). Does mass customization pay? An economic approach to evaluate customer integration. Production Planning \& Control, 15(4), 435-444.

Poetz, M. K., \& Schreier, M. (2012). The value of crowdsourcing: Can users really compete with professionals in generating new product ideas? Journal of Product Innovation Management, 29(2), 245-256.

Porter, M. E., \& Kramer, M. R. (2011). The big idea: Creating shared value. Harvard Business Review, 89(1), 2.

Schenk, E., \& Guittard, C. (2011). Towards a characterization of crowdsourcing practices. Journal of Innovation Economics, 1(7), 93-107.

Schwienbacher, A., \& Larralde, B. (2010). Crowdfunding of small entrepreneurial ventures. In Handbook of entrepreneurial finance. Oxford University Press, Forthcoming.

Shaw, E., \& Carter, S. (2007). Social entrepreneurship: Theoretical antecedents and empirical analysis of entrepreneurial processes and outcomes. Journal of Small Business and Enterprise Development, 14(3), 418-434.

Short, J. C., Moss, T. W., \& Lumpkin, G. T. (2009). Research in social entrepreneurship: Past contributions and future opportunities. Strategic Entrepreneurship Journal, 3(2), 161-194.

Siggelkow, N. (2002). Evolutiontowardfit. Administrative Science Quarterly, 47(1), 125-159.

Siggelkow, N. (2007). Persuasion with case studies. Academy of Management Journal, 50(1), 20-24.

Slootweg, R., Vanclay, F., \& van Schooten, M. (2001). Function evaluation as a framework for the integration of social and environmental impact assessment. Impact Assessment and Project Appraisal, 19(1), 19-28. 
Strauss, A., \& Corbin, J. (1990). Basics of qualitative research (Vol. 15). Newbury Park, CA: Sage Publications.

Strauss, A., \& Corbin, J. (1998). Basics of qualitative research. Thousand Oaks.

The Economist. (2013). Civic crowdfunding. breaking ground. Retrieved from http://www.economist.com/news/international/21578039-online-start-ups-are-rallying-citizens-revamp-their-neighbourhoods -breaking-ground

Vanclay, F. (2002). Conceptualising social impacts. Environmental Impact Assessment Review, 22(3), 183-211.

Vecchi, V., Casalini, F., \& Caselli, S. (2016). Impact investing as a societal refocus of venture capital. Principles and Practice of Impact Investing: A Catalytic Revolution, 62.

Vecchi, V., Casalini, F., Cusumano, N., \& Brusoni, M. (2014). Oltre venture: The first Italian impact investment fund. Impact Investing Lab, SDA Bocconi School of Management.

Wardrop, R., Zhang, B., Rau, R., \& Gray, M. (2015). Moving mainstream. The European Alternative Finance Benchmarking Report.

Wheat, R. E., Wang, Y., Byrnes, J. E., \& Ranganathan, J. (2013). Raising money for scientific research through crowdfunding. Trends in Ecology \& Evolution, 28(2), 71-72.

Wright, M., Lockett, A., Clarysse, B., \& Binks, M. (2006). University spin-out companies and venture capital. Research Policy, 35(4), 481-501.

Yin, R. K. (2009). Case study research: Design and methods. Essential guide to qualitative methods in organizational research. fourth. 